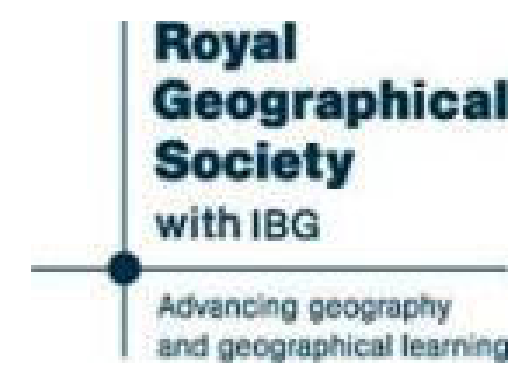

\title{
Gilbert's 'De Magnete'
}

On the Magnet... A New Physiology by William Gilbert

The Geographical Journal, Vol. 21, No. 6 (Jun., 1903), p. 663

Published by: The Royal Geographical Society (with the Institute of British Geographers)

Stable URL: http://www.jstor.org/stable/1775664

Accessed: $11 / 12 / 2014$ 15:08

Your use of the JSTOR archive indicates your acceptance of the Terms \& Conditions of Use, available at

http://www.jstor.org/page/info/about/policies/terms.jsp

JSTOR is a not-for-profit service that helps scholars, researchers, and students discover, use, and build upon a wide range of content in a trusted digital archive. We use information technology and tools to increase productivity and facilitate new forms of scholarship. For more information about JSTOR, please contact support@jstor.org. 
Yellowstone Park and the basalts of the Snake river, Idaho. The volume is thoroughly up to date, as it concludes with a few photographs of scenes in St. Vincent, West Indies, taken by Dr. Tempest Anderson during last summer, and a fine picture of Montagne Pelée in full eruption on the afternoon of July 9, 1902.

J. S. F.

\section{Gilbert's 'De Magnete.'}

William Gilbert, of Colchester, Physician of London. 'On the Magnet . . . a new Physiology.' London, 1900. Notes on the 'De Magnete' of Dr. William Gilbert. London: Privately printed. 1901.

The first of these volumes is a new and careful translation of Gilbert's famous work on the magnet, published under the auspices of the Gilbert club. The translation follows, page for page, the original Latin edition of 1600 , the general style of the latter being also retained as far as possible. It is printed at the Chiswick Press, and the whole "get-up" of the volume is most tasteful. The volume of explanatory notes, got together mainly through the energy and zeal of Prof. Silvanus Thompson, is a most valuable addition to the text, and bears witness to an extraordinary amount of research and an unusually extensive acquaintance with the literature both of Gilbert's time and the century preceding it. The allusions and references in the text are elucidated with great thoroughness, and though the greater part of the notes naturally have to do with questions of magnetic theory, there are various points of more strictly geographical interest on which much light is thrown. Thus the history of the so-called "loadstone-rock" in literature and cartography is fully dealt with, reference being made to the legends in Ruysch's map, the supposed northern voyage of Nicholas de Linna as mentioned by Hakluyt, and to Peter Plancius' location of the rock on his lost map described by Blundeville. References are given to the extensive literature on amber and the amber industry, and there are useful notes on various points connected with the compass and its use, the history of "wind-roses," and the various designations of the points of the compass. The term for the north-west used by GilbertBorrholybicus-is rarely met with, though one or two authorities for its use are cited. To these might be added a couple of still earlier instances, viz. the chart of the coast of Sweden from Waghenaer's 'Speculum Nauticum' of 1585, which is reproduced by Nordenskiöld in his 'Ptriplus,' and the treatise on the winds by Fabritius Paduanius (1601). The name is also given by Coronelli in his 'Epitome Cosmografica' of 1693 as the Græco-Latin term for the north-west wind.

\section{Practical Astronomy.}

- Grundzüge der Astronomisch-geographischen Ortsbestimmung auf Forschungsreisen und die Entwickelung der hierfür Massgebenden mathematish-geometrischen Begriffe.' Von Prof. Dr. Paul Güssfeldt. Mit 95 eingedruckten Abbildungen. Braunschweig : Druck und Verlag von Friedrich Vieweg und Sohn. 1902.

There are few men whose training and experience would render them better fitted to deal with the subject of practical astronomy for travellers than Prof. Paul Güssfeldt. His name has for years past been held in high esteem as that of a traveller and explorer of exceptional ability. His surveys in the Andes, West Africa, and elsewhere possess a scientific value and precision far in excess of those of the ordinary explorer, whilst his long experience as a university lecturer on mathematics has given bim an insight into the methods of instruction most suitable to the requirements of the student who is likely to become a geographical surveyor. The work which he has recently published is, therefore, worthy of special attention, and will doubtless be read with interest by many.

It will at once be seen that it differs considerably in design and arrangement 